\title{
STRATEGI PENGELOLAAN DALAM RANGKA MENINGKATKAN DAYA TARIK PASAR SENI ANCOL
}

\author{
Yudhistira Pratama1), Sylvie Wirawati2), B. Irwan Wipranata ${ }^{3)}$ \\ 1)Program Studi S1 PWK, Fakultas Teknik, Universitas Tarumanagara, yudhistama@gmail.com \\ 2) Program Studi S1 PWK, Fakultas Teknik, Universitas Tarumanagara, sylview@ft.untar.ac.id \\ 3) Program Studi S1 PWK, Fakultas Teknik, Universitas Tarumanagara, irwan_wipranata@yahoo.co.uk
}

Masuk: 05-08-2021, revisi: 04-09-2021, diterima untuk diterbitkan: 23-10-2021

\begin{abstract}
Abstrak
Pasar umumnya dikenal masyarakat sebagai tempat transaksi antara penjual dan pembeli. Namun terdapat pasar yang berbeda dari biasanya, yaitu Pasar Seni Ancol yang merupakan bagian dari destinasi wisata. Pasar seni ini merupakan wadah yang diperuntukan bagi seniman untuk bisa berkolaborasi dan mendapat apresiasi publik. Selain itu, juga ditujukan sebagai Ruang Terbuka Publik yang Rekreatif dan Edukatif bagi masyarakat dalam beraktifitas dan berkumpul. Pasar Seni Ancol dahulu pernah begitu populer dan menarik minat wisatawan lokal juga wisatawan mancanegara. Namun seiring dengan perkembangan teknologi dan trend, cara masyarakat dalam mengapresiasi seni telah berubah. Hingga saat ini kegiatan seni dan budaya di sana kurang di sorot dan dipromosikan. Oleh sebab itu tujuan utama dari penelitian ini adalah untuk memberikan usulan strategi pengelolaan dalam meningkatkan daya tarik, promosi dan penentuan brandimage yang sesuai guna meningkatkan minat masyarakat terhadap Pasar Seni Ancol. Selain itu, berkembangnya objek wisata ini diharapkan mampu meningkatkan perekonomian seniman/pengrajin di dalamnya dan mengedukasi masyarakat mengenai kesenian dan budaya. Penelitian ini merupakan penelitian deskriptif dengan pendekatan kualitatif. Pengumpulan data kualitatif dilakukan dengan melakukan survey lapangan ke lokasi wisata dan wawancara mendalam dengan beberapa narasumber terkait. Penelitian ini telah mendapatkan hasil berupa usulan strategi penglelolaan yang dapat digunakan dalam meningkatkan daya tarik, promosi dan penentuan brand image Pasar Seni Ancol.
\end{abstract}

Kata kunci: Daya Tarik; Pasar Seni; Pengelolaan Pariwisata; Promosi; Strategi Pengelolaan

\section{Abstract}

The market is generally known to the public as a place for transactions between sellers and buyers. However, there is a different market than usual, namely the Ancol Art Market which is part of a tourist destination. This art market is a place intended for artists to collaborate and get public appreciation. In addition, it is also intended as a Recreative and Educational Public Open Space for the community to carry out activities and gather. Ancol Art Market was once so popular and attracted local tourists as well as foreign tourists. However, along with technological developments and trends, the way people appreciate art has changed. Until now, arts and cultural activities there are less highlighted and promoted. Therefore, the main objective of this research is to propose a management strategy in increasing the attractiveness, promotion and determination of the appropriate brand image in order to increase public interest in the Ancol Art Market. In addition, the development of this tourist attraction is expected to be able to improve the economy of artists/craftsmen in it and educate the public about art and culture. This research is a descriptive research with a qualitative approach. Qualitative data collection was carried out by conducting field surveys to tourist sites and in-depth interviews with several related sources. This research has obtained results in the form of proposed management strategies that can be used in increasing the attractiveness, promotion and determination of the Ancol Art Market brand image.

Keywords : Art market; Attractiveness; Management Strategy; Promotion; Tourism Management 


\section{PENDAHULUAN}

\section{Latar Belakang}

Pasar Seni Ancol pada mulanya merupakan wadah yang diperuntukan bagi para seniman untuk bisa berkolaborasi dan mendapatkan apresiasi publik. Pada tahun 1975, Pasar Seni ini telah dibangun secara sederhana di antara Gelanggang Samudra dan Gelanggang Renang. Kegiatan Pasar Seni Ancol mulanya hanya dilangsungkan selama tiga hari setiap bulannya, setelah dilihat memiliki daya tarik yang luar biasa dilaksungkannya selama tujuh hari setiap bulannya. Selanjutnya minat pengunjung dan juga keinginan pekerja seni yang terus meningkat, maka itu dibangunlah sebuah kawasan permanen pada tanggal 17 Desember 1977 dan diresmikan oleh bapak Tjokropranolo yang saat itu menjabat sebagai Gubernur Jakarta. Kemudian dalam waktu singkat Pasar Seni Ancol terus mengalami kemajuan yang signifikan, sehingga dilakukannya perluasan kembali kawasan Pasar Seni Ancol pada tanggal 22 Agustus 1980 menjadi kurang lebih 5,25 hektar. Pada tahun 1984 dibangunlah sebuah bangunan dua lantai yang diberi nama Galeri Jaya Ancol, yang merupakan galerie pameran dan di lantai dua merupakan kantor manajemen dari Pasar Seni Ancol. Pada tahun 2009 pihak Pasar Seni melakukan peremajaan Galeri Jaya Ancol, bangunan tersebut diperluas dan diberi nama North Art Space. Selain itu Pasar Seni Ancol telah dilegkapi dengan 210 kios dan diantaranya merupakan 120 studio seniman serta puluhan ruang usaha kreatif.

Pasar Seni Ancol dahulu pernah begitu populer di tahun 1980 sampai dengan 1995, saat itu Pasar Seni Ancol tidak hanya menarik minat para wisatawan lokal namun juga dapat menarik minat wisatawan mancanegara. Pengunjung akan disambut dengan musik dan tari tradisonal daerah seperti keroncong, klenengan, dan tari ketuk tilu. Pasar Seni Ancol merupakan pusat kerajinan dan kesenian yang dapat memberikan inspirasi serta dapat menambah wawasan juga informasi pengunjung. Pasar seni Ancol beroprasional setiap hari dengan berbagai kesenian yang ditampilkan yaitu berupa seni kontenporer dan pertunjukan. Selain itu terdapat berbagai acara seni yang diadakan seperti Friday Jazz Night, Menjalin Kembali, Open Stage, Pengelaran Wayang Kulit, dan berbagai macam acara lainnya. Penggunjung juga dapat melakukan kegiatan lainnya seperti berswafoto, mengikuti kursus (Art Academy), dan menikmati wahana permainan.

Namun seiring perkembangan teknologi dan trend cara masyarakat dalam mengapresiasi seni telah mengalami perubahan. Hingga saat ini secara keseluruhan, seniman yang ada di Pasar Seni Ancol masih memakai media berkesenian tradisional seperti kanvas, kayu, tanah liat, dan logam belum terdapat inovasi baru dalam menyampaikan seni secara modern maupun digital. Selain itu pasar seni ancol memiliki image yang berbeda dari wilayah Taman Impian Jaya Ancol sendiri yang merupakan tempat rekreasi keluarga dengan wahana-wahana penuh atraksi. Untuk itu penelitian ini perlu dilakukan dalam rangka untuk melihat faktor-faktor pengelolaan yang dapat menambah daya tarik dari pasar seni dan dapat menambahkan minat pengunjung terutama kalangan muda, masyarakat umum terutama para pencinta seni. Tujuannya adalah untuk mendapatkan strategi pengelolaan dalam meningkatkan image branding dan daya tarik dari Pasar Seni Ancol sehingga kembali dikenal sebagai objek wisata pilihan baik lokal maupun mancanegara.

\section{Rumusan Permasalahan}

Rumusan permasalahan dalam penelitian ini adalah kurangnya daya tarik dan inovasi penyampaian hasil dari karya seni para pengrajin seni di Pasar Seni. Pasar Seni Ancol menampung lebih dari seratus seniman/pengrajin dan pengusaha kesenian didalamnya, dimana pasar seni merupakan wadah berkehidupan mereka. Tapi Pasar Seni Ancol sendiri terus mengalami kemunduran yang memberikan dampak besar bagi keberlangsungan seniman/pengrajin disana. Hal tersebut dikarenakan belum terdapat brand image pasar seni 
yang sesuai dengan perkembangan saat ini dan masih kurangnya informasi yang dapat dengan mudah dimengerti mengenai hasil karya seni yang ada dipasar seni.

\section{Tujuan}

Tujuan dari penelitian ini adalah untuk mengetahui kinerja pengelolaan Pasar Seni Ancol Jakarta, mengetahui daya tarik dari Pasar Seni Ancol Jakarta saat ini, dan Memberikan usulan strategi pengelolaan Pasar Seni Ancol Jakarta dalam rangka meningkatan daya tarik, promosi dan penentuan brand image guna menigkatkan minat masyarakat.

\section{KAJIAN LITERATUR}

\section{Pariwisata}

Definisi dari Pariwisata adalah kegiatan untuk melakukan perjalanan yang dilakukan sementara ke daerah tujuan wisata, dengan tujuan bukan untuk menetap dan tinggal ataupun mencari nafkah, melainkan untuk memenuhi rasa ingin tahu dan menghabiskan waktu senggang atau libur serta tujuan-tujuan lainnya (Meyers, 2009). Sedangkan menurut (Suyitno, 2005) pariwisata merupakan kegiatan bersifat sementara dengan tujuan tertentu untuk memperoleh kesenangan dan hiburan serta tidak bertujuan untuk mencari nafkah, tapi keberadaan dirinya dapat memberikan kontribusi pendapatan bagi masyarakat atau daerah yang dikunjungi dan juga perlu memanfaatkan beberapa komponen wisata misalnya sarana transportasi, objek wisata, restaurant, souvenir, akomodasi dan lain-lain. Selanjutnya, perlu dipahami mengenai Istilah pariwisata kreatif awalnya diciptakan oleh Crispin Raymond dan Greg Richards selama bekerja di Selandia Baru pada tahun 2000. Menurut (Raymond, 2003) Pariwisata kreatif adalah bagian dari pariwisata budaya, yang selanjutnya memperluas pengalaman mendalam dan otentik yang diinginkan oleh wisatawan. Selain itu pada buku Creative Tourism, a Global Conversation dikatakan pariwisata kreatif adalah pariwisata yang menawarkan kesempatan kepada pengunjung untuk mengembangkan potensi kreatif mereka melalui partisipasi aktif dalam kursus dan pengalaman belajar yang merupakan ciri khas dari destinasi liburan tempat mereka jalankan (Wurzburger, et al, 2009).

Kemudian untuk diketahui bahwa komponen penunjang pariwisata merupakan komponen kepariwisataan yang harus ada didalam destinasi wisata tersebut. Komponen kepariwisataan menurut (Buhalis, 2001) melalui teorinya komponen pariwisata terdiri dari 6A yaitu Attraction, Accessibility, Activity, Amenities, Accomodation, dan Ancillary. Dalam mengerti komponen pariwisata $6 \mathrm{~A}$ maka dijelaskan secara lebih rinci sebagai berikut :

a) Attraction (Atraksi) adalah segala hal yang mampu menarik minat para wisatawan untuk dapat menyempatkan diri berkunjung ke kawasan wisata atau secara khusus ingin datang untuk melakukan wisata.

b) Accessibility (Akses) adalah tingkat intensitas suatu daerah tujuan wisata atau destinasi wisata dapat dijangkau oleh wisatawan (Sugiama, 2011).

c) Activities (aktivitas) adalah kegiatan yang dapat dilakukan di destinasi yang akan memberikan pengalaman (experience) serta kenangan bagi wisatawan.

d) Amenities (Fasilitas Pendukung) adalah kelengkapan berbagai fasilitas yang sangat dibutuhkan di destinasi wisata.

e) Accommodation (Penginapan) diartikan sebagai tempat tinggal sementara di lokasi tujuan wisata yang tentunya di satu destinasi dengan destinasi lainnya pasti berbeda.

f) Ancillary Services adalah organisasi pengelola destinasi wisata. Organisasi pemerintah, asosiasi kepariwisataan, tour operator dan lain-lain.

\section{Pasar Seni}

Pasar seni adalah tempat pembeli dan penjual yang memperdagangkan komoditas, jasa, dan karya seni. Pasar seni beroprasi dalam model ekonomi yang mempertimbangkan lebih dari 
penawaran saja, dimana seni dibeli dan dijual berdasarkan nilai-nilai yang tidak hanya didasarkan pada nilai budaya suatu karya, tetapi juga pada nilai sejarahnya. Pasar seni dapat dibagi dua yaitu menjadi pasar primer dan pasar sekunder. Pasar primer adalah tempat karya pertama kali dijual setelah dibuat oleh seorang seniman; pasar sekunder berurusan dengan penjualan ulang berikutnya, baik melalui transaksi pribadi dealer atau lelang. Lelang sering kali dianggap sebagai satu-satunya patokan yang layak untuk nilai suatu objek, karena proses pembentukan harga dapat diamati secara terbuka dan hasilnya secara umum diterima sebagai tujuan (Spieth, 2020). Dalam pelaksanaannya pasar seni dapat dibedakan kedalam beberapa jenis pasar seni, yaitu :

a) Pasar Seni Nasional adalah pasar seni yang menampung karya seni dan seniman yang berasal dari berbagai daerah diseluruh nusantara.

b) Pasar Seni dan Budaya adalah pasar seni yang menampung kegiatan seni dan seniman berskala regional.

c) Pasar Seni Khas adalah pasar seni yang menampung kegiatan seni dan seni khusus dari suatu daerah.

d) Pasar Seni Temporer adalah pasar seni yang keberadaannya tidak permanen, kegiatannya biasa berada pada tempat-tempat yang berdekatan dengan objek wisata.

\section{Strategi Pengelolaan}

Konsep dan perumusan strategi penting untuk diaplikasikan dalam pengelolaan. Perencanaan menjadi alat yang paling penting untuk memberikan arahan dan batasan untuk mencapai tujuan dari kegiatan pengembangan. Pengertian strategi menurut (Rangkuti, 2013) merupakan perencanaan induk yang dilakukan secara komprehensif, dan akan menjelaskan bagaimana suatu organisasi dalam usaha mencapai seluruh tujuan yang telah ditetapkan berdasarkan misi yang sudah ditentukan sebelumnya. Selain itu menurut (Siagian, 2004) pengertian dari sebuah strategi ialah suatu metode atau rencana yang telah dipilih untuk membawa masa depan yang diharapkan, misalnya dalam melaksanakan pencapaian tujuan dan solusi untuk masalah. Sedangkan pengelolaan mememiliki arti yang sama dengan manajemen, yang berarti terlibat dalam pengaturan atau pengurusan. Sehingga dapat dikatakan bahwa pengelolaan merupakan suatu kegiatan dalam melaksanakan proses perencanaan dan pengambilan keputusan, pengorganisasian, serta kepememimpinan suatu organisasi dengan melihat aspek keuangan, fisik dan informasi sumber daya untuk mencapai tujuan secara efisiensi dan efektif. Sehingga strategi pengelolaan dimaksudkan sebagai suatu pola atau rencana yang digunakan dalam menciptakan dan mempertahankan kondisi objek agar tetap optimal, effektif, dan efisien untuk mencapai tujuan.

\section{Benchmarking}

Benchmarking adalah suatu proses yang digunakan dalam manajemen atau umumnya manajemen strategis, dimana suatu unit organisasi harus mengukur dan membandingkan kinerjanya terhadap aktivitas atau kegiatan serupa lain yang sejenis baik secara internal maupun eksternal. Dari hasil benchmarking, suatu organisasi dapat memperoleh gambaran dalam (insight) mengenai kondisi kinerja organisasi sehingga dapat mengadopsi best practice untuk meraih sasaran yang diinginkan. Tujuan utama Benchmarking adalah untuk mengevaluasi proses ataupun produk saat ini, sehingga dapat ditemukan cara atau langkah tebaik untuk meningkatkan proses maupun kualitas produk. Terdapat 4 cara yang dapat digunakan dalam menerapkan Benchmarking yaitu :

a) Riset in-house dengan melakukan penilaian terhadap internal maupun informasi mengenai perusahaan dari publik.

b) Riset pihak ketiga menunjuk perusahaan surveyor untuk melakukan kegiatan Benchmarking. 
c) Pertukaran informasi secara langsung melaui kuesioner, survey, wawancara, dll.

d) Melakukan kunjungan langsung ke lokasi mitra dari kegiatan Benchmarking tersebut, cara ini dapat dianggap yang paling efektif.

Penggunaan metode benchmarking dapat memberikan banyak keuntungan, salah satunya terciptanya suatu siklus yang mendorong perbaikan yang terus menerus sehingga dapat terbentuk proses maupun produk terbaik. Selain itu jika suatu jaringan dan kemitraan dalam benchmarking telah terbentuk maka berbagai praktik baik dan terbaik dapat saling dibagi di antara mereka. Penerapan benchmarking dapat di lakukan berdasarkan jenisnya, berikut ini 7 macam jenis benchmarking:
a) Internal Benchmarking
b) Competitive Benchmarking
c) Functional Benchmarking
d) Generic Benchmarking
e) Process Benchmarking
f) Performance Benchmarking
g) Strategic Benchmarking

\section{Pemasaran/Promotion}

Marketing Mix berfungsi sebagai alat yang digunakan untuk bertahan dalam lingungan kompetitif. Konsep ini dikendalikan oleh suatu organisasi dan terdiri dari empat elemen yaitu; produk, harga, tempat, dan promosi. (Owomoyela, et al), namun dalam penelitian ini hanya akan difokuskan kedalam tiga elemen yaitu; produk, tempat, dan promosi. Marketing Mix adalah "Kumpulan alat pemasaran taktis yang dapat dikontrol dan dipadukan perusahaan untuk menghasilkan respon yang diinginkan di pasar sasaran" tujuan utamanya adalah untuk memenuhi kebutuhan dan keinginan pasar yang dibidik:

a) Produk merupakan komponen pertama dari marketing mix dan dapat mempengaruhi tiga elemen lainnya, karena sifat dan atributnya.

b) Tempat merupakan salah satu komponen marketing mix dan meliputi saluran distribusi, moda transportasi, lokasi strategis, menyenangkan dan efisien.

c) Promosi adalah salah satu komponen paling kuat dalam marketing mix. Promosi adalah cara suatu perusahaan dalam mengkomunikasikan dan mngajak pasar sasaran untuk membeli produk perusahaan. Konsep promosi mencakup semua kegiatan pemasaran yang digunakan untuk menginformasikan, membujuk, dan mengingatkan pasar sasaran tentang suatu perusahaan dan produk atau jasanya, sedemikian rupa untuk membangun citra yang menguntungkan di benak pelanggan. 


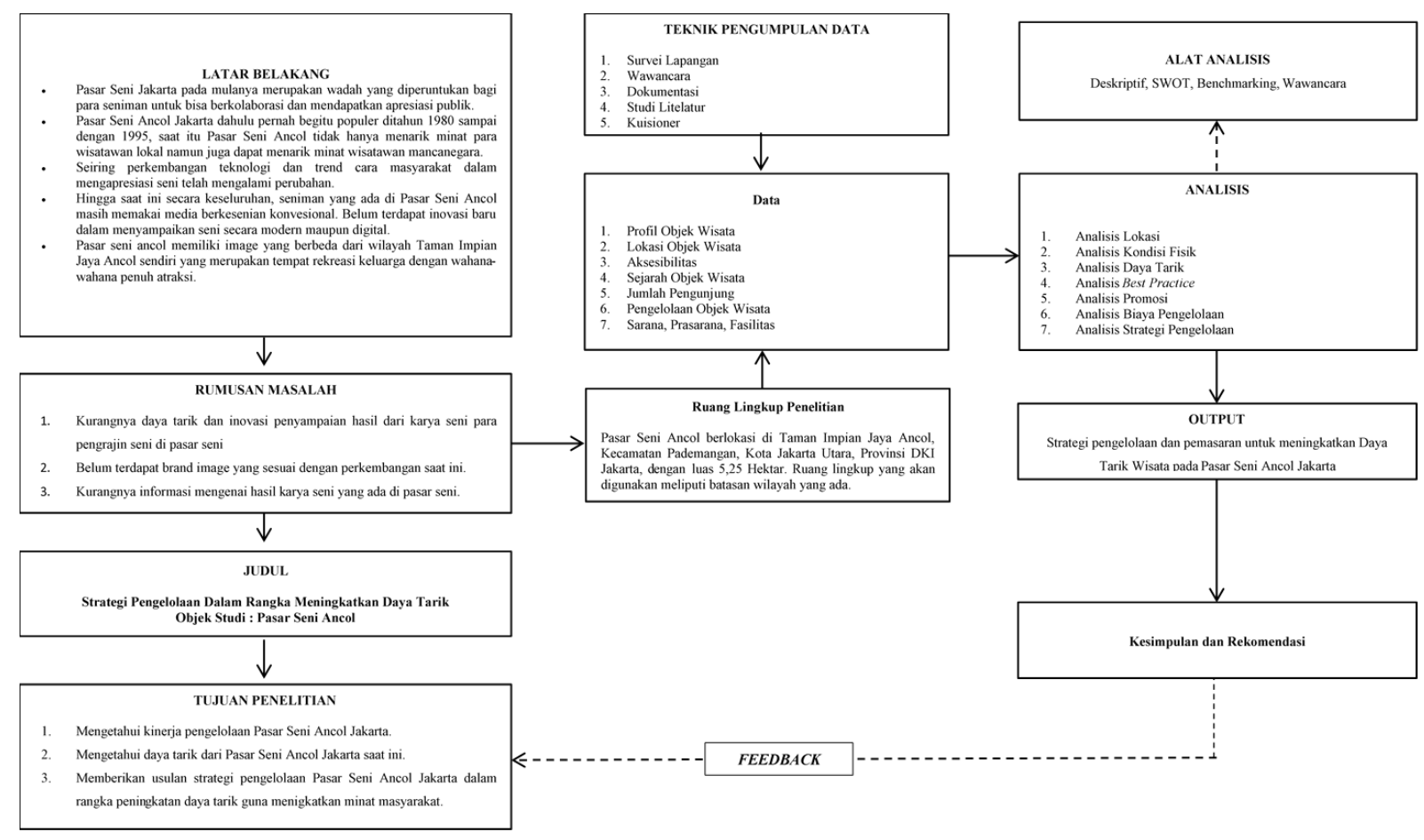

\section{METODE}

Dalam pengerjaan penelitian ini terdapat empat metode pengumpulan data yang digunakan yakni observasi lapangan, wawancara, dokumentasi dan studi literatur. Untuk metode analisis yang digunakan ada tiga metode yaitu metode kualitatif yang digunakan untuk mengetahui kondisi dan daya tarik Pasar Seni Ancol saat ini, metode komparatif yang digunakan untuk membandingkan kesesuaian pengelolaan saat ini dengan standar pengelolaan yang ada dengan objek pembanding lainnya, dan metode SWOT yang digunakan untuk menemukan masalah dari empat sisi berbeda sekaligus untuk membantu dalam perumusan usulan strategi pengelolaan Pasar Seni Ancol dalam penelitian ini.

\section{DISKUSI DAN HASIL}

Pasar Seni Ancol pada mulanya merupakan wadah yang diperuntukan bagi para seniman dibangun secara sederhana dan diadakan secara temporer pada tahun 1975. Namun setelah melihat bahwa Pasar Seni Ancol Jakarta ini memiliki daya tarik besar maka itu di bangunlah sebuah kawasan permanen pada tanggal 17 Desember 1977. Kemudian dilakukannya perluasan kembali kawasan Pasar Seni Ancol pada tanggal 22 Agustus 1980 menjadi 5,25 hektar dan setelah itu pada tahun 1984 dibangunlah sebuah bangunan dua lantai yang diberi nama Galeri Jaya Ancol. Hingga tahun 2009 pihak Pasar Seni melakukan peremajaan Galeri Jaya Ancol, bangunan tersebut diperluas dan diberi nama North Art Space. Saat ini Pasar Seni Ancol telah dilegkapi dengan 210 kios dan diantaranya merupakan 120 studio seniman serta puluhan ruang usaha kreatif.

Pasar seni terus berkembang dan menjadi tempat untuk pengunjung dapat berinteraksi langsung dengan para seniman dan menyaksikan maupun terlibat secara langsung dalam proses pembuatan karya seni. Selain itu Pasar Seni Ancol merupakan tempat melaksanakan kegiatan tawar menawar antara para seniman dengan pengunjung yang ingin membeli karya seni mereka. Pasar Seni Ancol saat ini menawarkan berbagai pilihan aktivitas menarik yang bisa dinikmati bersama teman, organisasi/komunitas, anak dan keluarga. Terdapat 6 pilihan event yang dapat digelar seperti:

a) Gathering seperti family gathering, corporate gathering, reuni akbar, maupun lauching 
produk dapat diadakan.

b) Sportainment, event yang dapat diterapkan seperti; fun run/walk, fun bike, fit festival, yoga festival, zumba dan sebagainya yang dapat dikolaborasikan dengan entertainment sesai konsep pribadi.

c) Seni \& Budaya, event seni budaya seperti lomba untuk anak- anak, sanggar-sanggar tari ataupun dapat melakukan pergelaran wayang kulit dan karawitan.

d) Komunitas, event komunitas yang dapat diakomodir seperti sosialisasi komunitas sastra, fotografi, pencinta otomotif, ataupun institusi tertentu dapat berekspresi di pasar seni.

e) Industri Kreatif, event dengan tema indutri kreatif seperti kreatif market ataupun kerajinan-kerajinan menarik lainnya.

f) Edukasi, event yang mengandung unsur edukasi sangan mungkin dan sering dihadirkan di Pasar Seni seperti ReKreasi, fieldtrip, belajar membatik, membuat keramik, membuat wayang betawi, membuat robot dari barang bekas dan masih banyak lagi.

\section{Analisis Lokasi}

Analisis ini bertujuan untuk mengetahui karakteristik dari keadaan sekitar dari lokasi objek wisata Pasar Seni Ancol hal ini dilakukan untuk mengetahui potensi yang dimiliki berdasarkan lokasi dan keadaan eksisting lokasi tersebut. Area Pasar Seni Ancol saat ini berlokasi berdekatan dengan Atlantis Water Adventure tepatnya berada di Jalan Binaria 1 setelah masuk dari Jalan Gerbang Ancol, Taman Impian Jaya Ancol. Luas total dari area wisata Pasar Seni Ancol yaitu 5,25 ha.

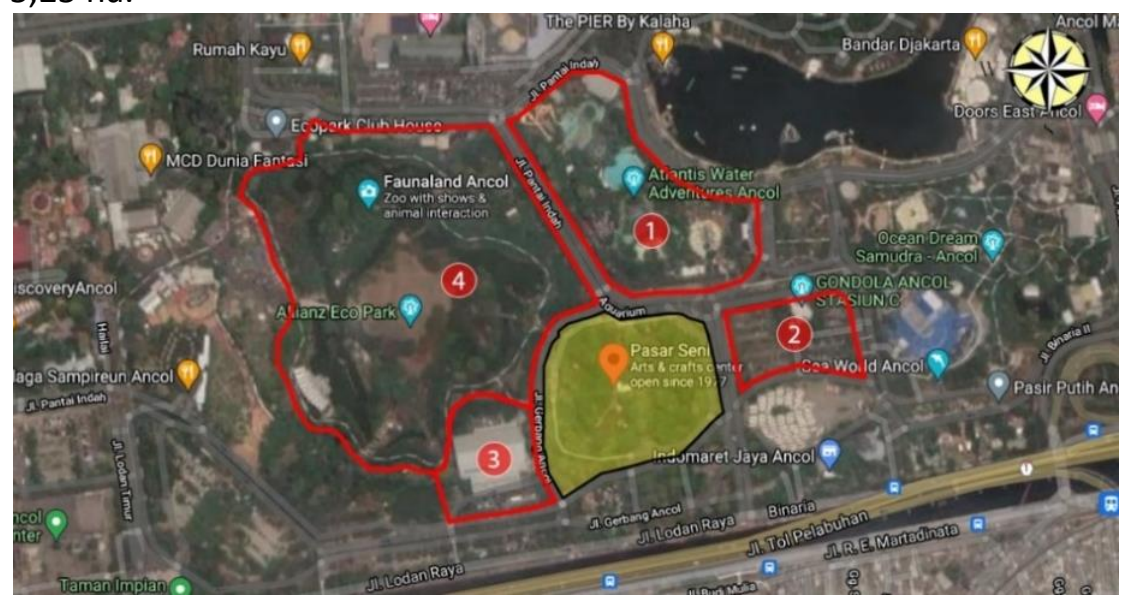

Gambar 1. Peta Batas Area Pasar Seni Ancol

Sumber: Google Earth, 2021

- Batas Utara : Atlantis Water Adventure (1)

- Batas Selatan : Jalan Gerbang Ancol

- Batas Timur : Stasiun Gondola Ancol (2)

- Batas Barat : Ecovention (3) dan Allianz Eco Park (4)

Kemudian untuk aksesibilitas akan dijelaskan tentang cara menjangkau atau cara menuju area Pasar Seni Ancol dari Kota Jakarta, Kota Bogor, Kota Depok, Kota Tangerang, Kota Tangerang Selatan, dan Kota Bekasi. Untuk menuju Pasar Seni Ancol sudah terdapat banyak pilihan yang dapat digunakan baik menggunakan kendaraan pribadi transportasi umum seperti transjakarta, kereta ataupun transportasi online. 


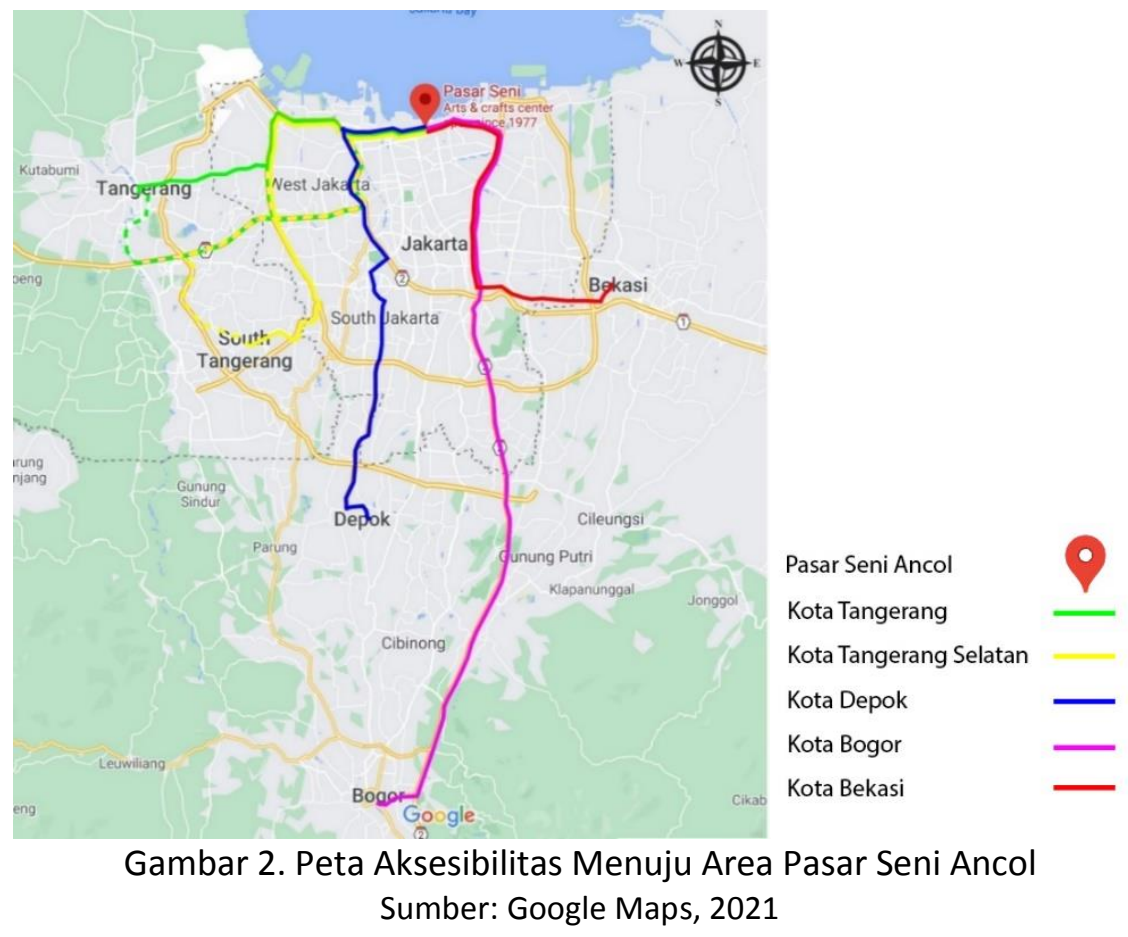

Namun saat menggunakan kendaraan pribadi pengunjung diharuskan menyiapkan uang lebih untuk membayar tiket masuk kendaraan pribadi, untuk pengguna mobil sebesar Rp.25.000 dan pengguna kendaraan roda dua sebesar RP 15.000. Pada gambar 2. dapat dilihat bahwa akses yang banyak disarankan untuk pengguna kendara pribadi merupakan jalur yang melalui Jalan tol, baik itu lingkar luar maupun lingkar dalam. Berikut ini merupakan tabel jalur aksesibilitas yang dapat ditempuh menuju Pasar Seni Ancol:

Tabel 3. Aksesibilitas dari dan menuju Pasar Seni Ancol

\begin{tabular}{|c|c|c|c|c|}
\hline Asal Kota & Jarak & Waktu dari & $\begin{array}{l}\text { Waktu } \\
\text { Menuju }\end{array}$ & Keterangan \\
\hline \multirow[t]{2}{*}{ Jakarta Selatan } & $24,7 \mathrm{Km}$ & 33 Menit & 31 Menit & Via Jakarta Inner Ringroad \\
\hline & $21 \mathrm{Km}$ & 39 Menit & 36 Menit & Via Jl. Jend. Sudirman \\
\hline \multirow[t]{2}{*}{ Jakarta Timur } & $22,1 \mathrm{Km}$ & 26 Menit & 28 Menit & Via Jakarta Inner Ringroad \\
\hline & $24,7 \mathrm{Km}$ & 31 Menit & 38 Menit & Via Jl. Gn. Sahari \\
\hline \multirow[t]{2}{*}{ Jakarta Barat } & $13,2 \mathrm{Km}$ & 25 Menit & 22 Menit & Via Jakarta Inner Ringroad \\
\hline & $13,9 \mathrm{Km}$ & 29 Menit & 29 Menit & Via Jl. Raya Pantura \\
\hline Jakarta Utara & $13,9 \mathrm{Km}$ & 28 Menit & 20 Menit & $\begin{array}{l}\text { Via Jl. R. E. Martadinata dan JI. } \\
\text { Yos Sudarso }\end{array}$ \\
\hline \multirow[t]{2}{*}{ Tangerang } & $28,3 \mathrm{Km}$ & 41 Menit & 39 Menit & Via Jl. Daan Mogot \\
\hline & $39,2 \mathrm{Km}$ & & 44 Menit & Via Jakarta Outer Ringroad \\
\hline \multirow[t]{2}{*}{ Tangerang Selatan } & $41,4 \mathrm{Km}$ & 46 Menit & 42 Menit & Via Jakarta Outer Ringroad \\
\hline & $31,9 \mathrm{Km}$ & 71 Menit & 62 Menit & Via Jl. Jend. Sudirman \\
\hline \multirow[t]{2}{*}{ Depok } & $51,9 \mathrm{Km}$ & 58 Menit & 57 Menit & Via Jakarta Inner Ringroad \\
\hline & $40,8 \mathrm{Km}$ & 82 Menit & 76 Menit & Via JI. Jend. Sudirman \\
\hline \multirow[t]{2}{*}{ Bogor } & $65,4 \mathrm{Km}$ & 61 Menit & 57 Menit & Via Jl. Tol Jagorawi \\
\hline & $63,5 \mathrm{Km}$ & 108 Menit & 124 Menit & Via Jl. Raya Jakarta-Bogor \\
\hline \multirow[t]{2}{*}{ Bekasi } & $32 \mathrm{Km}$ & 37 Menit & 38 Menit & Via Jakarta Outer Ringroad \\
\hline & $29 \mathrm{Km}$ & 48 Menit & 55 Menit & Via Jl. I Gusti Ngurah Rai \\
\hline
\end{tabular}

Sumber: Hasil Olahan Penulis, 2021

Selain menggunakan kendaraan pribadi, pengunjung juga dapat memanfaatkan transportasi 
umum yang sudah tersedia saat ini seperti transjakarta dan kereta api. Berikut ini rute transportasi umum yang dapat digunakan :

Tabel 4. Rute Transportasi Umum Menuju Pasar Seni Ancol

\begin{tabular}{ccc}
\hline Jenis & Koridor & Rute \\
\hline Transjakarta & 5 & Kampung Melayu - Ancol \\
\hline Transjakarta & $5 \mathrm{D}$ & PGC - Ancol \\
\hline Transjakarta & $5 \mathrm{E}$ & Kampung Rambutan - Ancol \\
\hline Transjakarta & $5 \mathrm{H}$ & Bogormon - Jakarta Kota \\
\hline Commuter Line & & Bekasi - Jakarta Kota \\
\hline Commuter Line & & Serpong - Tanah Abang - Kp. Bandan \\
\hline Commuter Line & & Depok - Jakarta Kota \\
\hline Commuter Line & & Tangerang - Duri - Kp. Bandan
\end{tabular}

Sumber: Hasil Olahan Penulis, 2021

\section{Analisis Daya Tarik}

Daya tarik wisata dapat menarik dikunjungi bila memenuhi beberapa syarat, yaitu something to see, something to do, dan something to buy. Pasar Seni Ancol memiliki daya tarik wisata yang jarang atau tidak dimiliki oleh tempat lain, yaitu Pasar Seni Ancol sebagai wadah yang diperuntukan bagi para seniman untuk bisa berkolaborasi dan dari situlah pengunjung dapat menyaksikan dan memberikan apresiasi kepada para seniman yang berkarya disana. Pengunjung maupun khususnya para pencinta seni dapat menikmati seni kontemporer, pasar seni melalui para seniman juga menampilkan berbagai seni seperti patung pahat, karikatur, lukisan, kerajian keramik, fotografi, relief, tambiar dan lainnya. Selain itu juga sering diadakan acara musik, open stage, pengelaran tari, pagelaran wayang kulit, pertujukan tradisional, seminar, pameran serta pemutaran film kesenian. Kemudian pengunjung dapat mengikuti 6 jenis program kegiatan yang sekiranya dapat dilaksanakan di Pasar Seni seperti gathering, aktivitas olahraga, aktifitas seni dan budaya, aktivitas komunitas, industri kreatif, dan edukasi. Selain itu di Pasar Seni banyak menjual souvenir kerajinan tangan seperti kalung, gelang, dan berbagai hiasan lainnya. Bagi pengunjung yang hanya bertujuan untuk bersantai di Pasar Seni juga dapat menikmati berbagai hidangan menarik baik makanan dan minuman yang dijual di sana seperti kopi, air tebu, bir pletok, nasi uduk, ketoprak, gado-gado dan berbagai makanan tradisional betawi lainnya. Saat ini dimasa pandemi terjadi banyak pembatasan yang diterapkan, sehingga terdapat beberapa event atau acara yang belum bisa dinikmati kembali. Namun pengunjung masih bisa menikmati karya seni kontemporer para seniman ketika berkunjung ke Pasar Seni Ancol. Tetapi untuk pegelaran acara musik, open stage, tari dan sebagainya yang merupakan event dengan melibatkan banyak masa belum bisa diselenggarakan.

\section{Analisis Best Practice}

Penerapan best practice berguna untuk mengetahui tingkat keberhasilan yang telah dicapai dengan cara menganalisis objek studi dengan studi pembanding. Objek wisata yang memiliki konsep serupa dengan objek studi adalah Dafen Oil Painting Village yang berlokasi di Shenzhen, Guangdong, China dan Creative Hub M-Bloc Space yang berlokasi di Kebayoran Baru, Jakarta Selatan, DKI Jakarta. Objek Wisata Dafen Oil Painting dan objek studi memiliki persamaan konsep wisata, yaitu sebagai pusat seni dan budaya. Sedangkan M-Bloc Space memiliki konsep creative hub atau pusat kreatif sebagai ruang kreatif public yang memiliki sejumlah restoran dan kios produk local, venue music, serta area outdoor. dalam pengelolaan kawasan yang berguna untuk mengetahui kelebihan dan kekurangan melalui perbandingan 
antara Dafen Oil Painting serta M-Bloc Space terhadap objek studi dengan membandingkan aspek - aspek tersebut.

Tabel 5. Objek Studi Pembanding

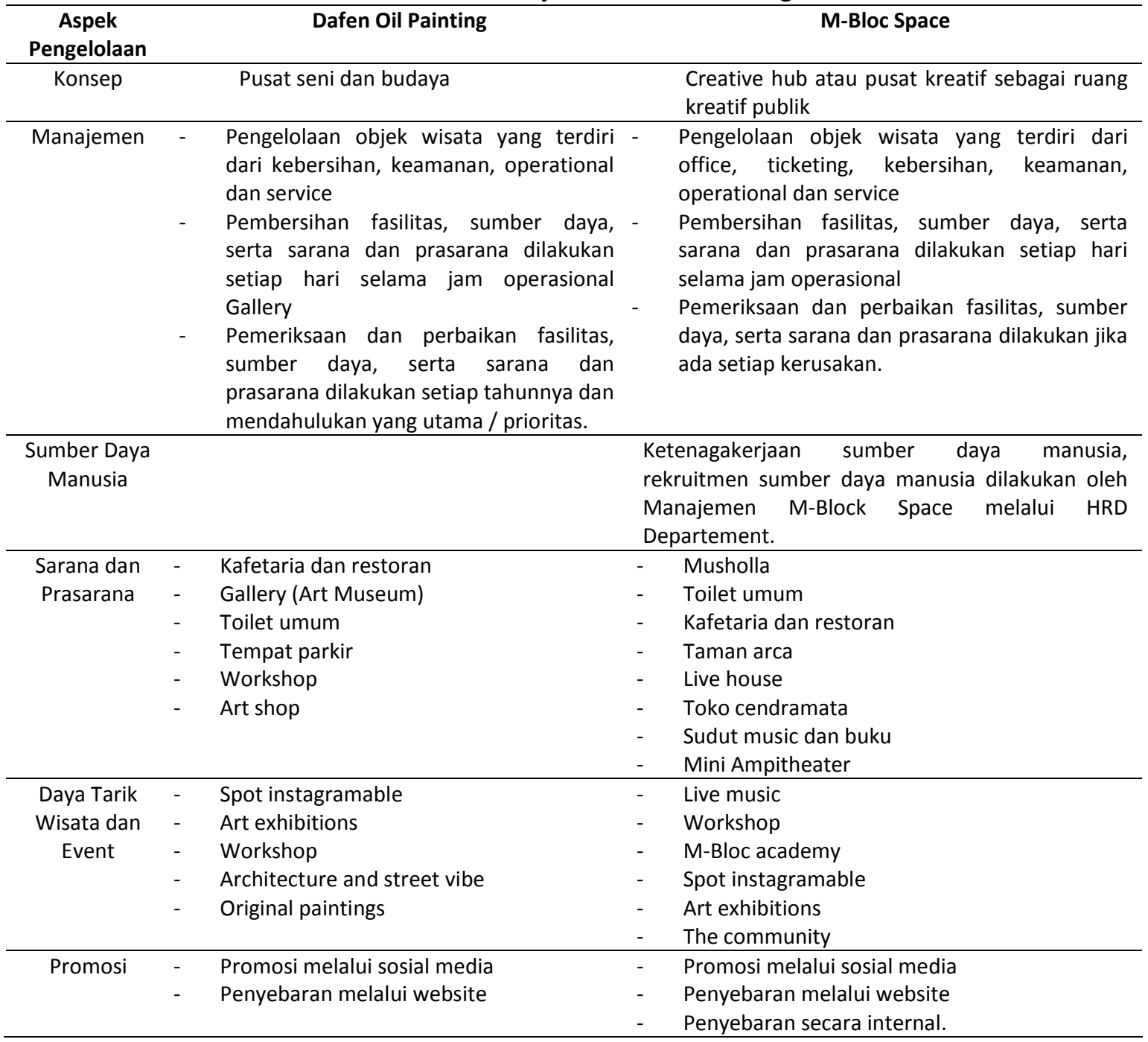

Sumber: Hasil Olahan Penulis, 2021

\section{Analisis Promosi}

Kegiatan promosi dapat dianggap penting untuk sebuah destinasi wisata, karena promosi memiliki peran besar dalam memperkenalkan suatu objek atau destinasi wisata kepada wisatawan baik local maupun mancanegara. Dengan harapan wisatawan dapat mengetahui informasi tentang objek wisata tersebut dengan lebih baik dan memunculkan rasa ketertarikan untuk datang berkunjung. Berdasarkan hasil wawancara dengan Pengelola Pasar Seni Ancol. Berdasarkan hasil temuan dari survey lapangan dan hasil pembahasan yang telah dilakukan maka dapat ditarik kesimpulan bahwa di dalam aspek media promosi, upaya promosi yang dilakukan saat ini telah menggunakan banyak ragam media sebagai sarana promosi. Namun sebagian besar upaya promosi ini dilakukan oleh pihak Taman Impian Jaya Ancol secara keseluruhan sehingga masih kurangnya upaya promosi yang secara specifik membranding Pasar Seni Ancol. Meskipun demikian dapat dinilai, hal ini telah menjadi tanda yang bagus karena dengan adanya keberagaman media promosi yang digunakan maka dapat menambah peluang untuk menjangkau lebih banyak kalangan calon wisatawan agar tertarik untuk berkunjung ke Taman Impian Jaya Ancol dan lebih diharapkan untuk berkunjung ke Pasar Seni Ancol. 


\section{Analisis Strategi Pengelolaan}

Analisis strategi dilakukan untuk menganalisis hasil dari keseluruhan analisis yang telah dilakukan, menganalisis strategi yang telah dilakukan pihak pengelola Pasar Seni Ancol, serta mengetahui strategi pengelolaan yang dapat diterapkan terhadap Pasar Seni Ancol. Berdasarkan seluruh hasil analisis, maka perlu dilakukan penyusunan suatu sistem atau struktur organisasi yang dapat dijalankan oleh pihak pengelola Pasar Seni dalam melaksanakan seluruh kegiatan pengelolaan dan bertujuan untuk mempermudah pembagian tugas serta tanggung jawab. Setiap bagian memiliki tugas dan fungsinya tersendiri, tugas tersebut juga harus didasari oleh Standar Operasional prosedur (SOP) dan rencana kerja jangka pendek maupun rencana jangka panjang. Berikut adalah tugas dari setiap bagian dan bidang dalam organisasi. Sehingga berdasarkan hasil analisis yang telah dilakukan, Berikut ini merupakan struktur organisasi yang dapat diterapkan:

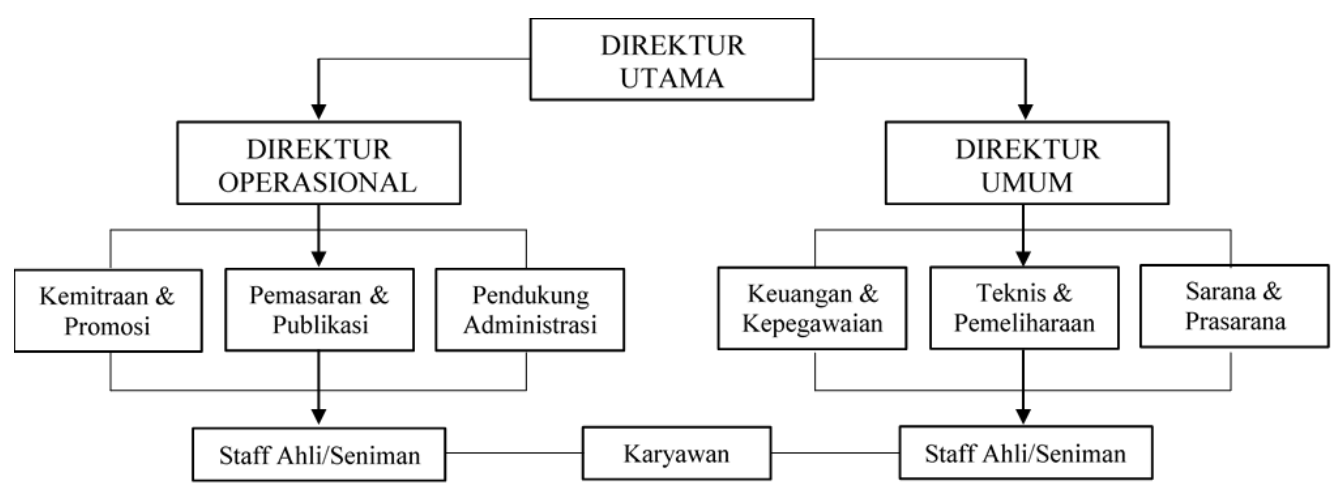

Gambar 3. Usulan Struktur Organisasi Pengeloalan Sumber: Olahan Penulis

Langkah terakhir adalah untuk mengetahui strategi pengelolaan yang dapat diterapkan terhadap Pasar Seni Ancol dalam bentuk analisis SWOT. Berikut adalah usulan strategi pengelolaan untuk kawasan Pasar Seni berdasarkan hasil tabel SWOT.

a) Melakukan revitalisasi berdasarkan rencana yang telah dibuat sebelumnya pada kawasan Pasar Seni Ancol.

b) Mengusulkan kerjasama dengan berbagai komunitas seni, lembaga pendidikan, objek wisata sejenis, penginapan / hotel terdekat dalam menyelenggarakan acara-acara, festival, event nasional maupun internasional serta promosi di Pasar Seni Ancol.

c) Mempelajari dan menerapkan hasil analisi best practices berupa sistem organisasi pengelolaan dari objek studi sejenis.

d) Mengembalikan dan memperkuat komunitas seniman Pasar Seni seperti dahulu dengan memberlakukan seniman sebagai mitra dan dapat mengkomunikasikan atau mendiskusikan bersama segala keputusan yang diambil maupun peraturan yang ditetapkan. Serta membantu dalam mengikut sertakan hasil karya seni para seniman pada pameran-pameran nasional maupun internasional sekaligus bekerja sama dengan galerie di Indonesia untuk menampilkan karya para seniman Pasar Seni.

e) Membuat rencana untuk mengadakan pameran seni yang berisi karya seniman Pasar Seni yang dikombinasikan / dipamerkan bersama dengan karya seni seniman terkemuka di Indonesia.

f) Menggunakan Multibahasa Serta Memanfaatkan 5 Panca Indra dalam Menampilkan Karya Seni dalam galleri.

g) Memanfaatkan media digital dalam menyelenggarakan pameran, aktivitas, dan promosi di Pasar Seni Ancol. 
h) Melakukan Seni Pertunjukan Secara Virtual dalam menjaring pengunjung melalui media sosial seperti youtube, instagram, dan facebook secara live dan berkala.

i) Menampilkan Karya Berproses, untuk membantu mendeliver nilai-nilai karya tersebut.

j) Memanfaatkan Online Marketplace sebagai media memasarkan hasil karya seni para seniman pasar seni.

k) Memperluas segmen pasar tidak hanya kepada masyarakat dan komunitas pencinta seni misalnya dengan berkerjasama dengan komunitas lainnya.

I) Melakukan branding dengan memanfaatkan ciri khas dari Pasar Seni sebgai objek wisata seni dan budaya.

m) Meningkatkan kualitas pengelolaan dalam aspek - aspek tertentu sehingga dapat memberikan pengalaman menarik untuk para pengunjung.

\section{KESIMPULAN DAN SARAN Kesimpulan}

Berdasarkan hasil penelitian dapat diketahui bahwa kinerja pengelola Pasar Seni Ancol melalui observasi dan wawancara sangat mempengaruhi kondisi pasar seni saat ini, dengan dilakukan berbagai analisis dapat disimpulkan kinerja pengelola belum optimal dalam berbagai hal seperti dilihat melalui kondisi fisik, promosi, strategi yang dijalankan, dan jumlah pengunjung saat ini yang mengalami penurunan bahkan disaat sebelum pandemi. Kemudian penelitian ini juga dapat menjabarkan berbagai daya tarik yang terdapat pada Pasar Seni Ancol yaitu seperti, Pasar Seni Ancol sebagai wadah serta tempat berkumpul para seniman untuk berkolaborasi, kemudian sebagai tempat belanja aneka benda seni, tempat edukasi yang memberikan pengetahuan dan keterampilan akan kesenian, salah satu tempat untuk berwisata kuliner, sebagai tempat berkumpul dan berolahraga bersama, dan juga sebagai pusat kesenian dan budaya sekaligus merupakan pusat ruang kreatif publik. Lalu yang terakhir, penelitian ini dapat memberikan beberapa usulan strategi dalam peneglolaan untuk meningkatkan daya tarik, promosi, dan penentuan brand imagenya. Beberapa usulan tersebut yaitu sebagai berikut, melakukan revitalisasi dan peremajaan kawasan, melakukan kerjasama dengan berbagai komunitas, berkerjasama dengan seniman-seniman ternama, memanfaatkan media digital dalam menyelenggarakan pameran atau pertunjukan virtual, mengikut sertakan koleksi dan hasil karya para seniman disana, memperluas segmen pasar tidak hanya kepada masyarakat pencinta seni, melakukan branding sebagai objek wisata seni dan budaya, menggunakan multibahasa dan memanfaatkan 5 panca indra dalam menampilakan karya seni dalam galerie, menampilkan karya berbroses untuk membantu mendeliver nilai-nilai karya tersebut sehingga mudah dipahami.

\section{Saran}

Setelah dilakukan penelitian ini penulis ingin memberikan saran kepada beberapa pihak yaitu kepada, a) Badan pengelola Pasar Seni Ancol sebagai unit pengelola baiknya melakukan komunikasi dan diskusi baik kepada seniman didalamnya maupun berbagai komunitas seni yang ada. Hal tersebut penulis anggap dapat berguna untuk memperoleh pendapat ataupun usulan dalam pengambilan keputusan, sehingga pihak pengelola dapat mengikuti perkembangan seni saat ini dan mengetahui kebutuhan masyarakat yang bersangkutan dengan pengelolaan Pasar Seni Ancol tersebut. Kemudian untuk, b) Pasar Seni Ancol itu sendiri harus dapat mengambil peluang dalam perkembangan seni saat ini sehingga dapat memberikan pengalaman baru kepada pengunjung dengan memanfaatkan teknologi ke dalam acara/pameran/workshop yang dijalankan.

Selanjutnya kepada pihak yang akan melanjutkan studi dan menggunakan jurnal ini, studi pengelolaan Pasar Seni Ancol ini dapat dijadikan studi lanjutan kedalam berbagai aspek lainnya seperti; pengembangan sistem kelembagaan komunitas seniman, menejemen pengelolaan pasar seni ancol, pasar seni ancol sebagai cagar budaya dan sebagainya. 


\section{REFERENSI}

Buhalis, D. (2001). Tourism Distribution Channels. London: Cengage Learning EMEA.

Meyers, K. (2009). Mentawai. Romain Pages Editions.

Owomoyela, et al (2013). Investigating the impact of marketing mix elements on consumer loyalty: An empirical study on Nigerian Breweries Plc. New York: The Free Press.

Rangkuti, F. (2013). Strategi Semut Melawan Gajah. Jakarta: Gramedia Pustaka Utama.

Raymond, C. (2003). Creative Tourism New Zealand. North Brabant: Tilburg University.

Siagian, S. P. (2004). Manajemen Sumber Daya Manusia. Jakarta: Bumi Aksara.

Spieth, D. A. (2020). Art Markets. Oxford Art Online: Retrieved October 28, 2020, from https://www.oxfordartonline.com/page/art-markets

Spillane, J. (1994). Pariwisata Indonesia : Siasat Ekonomi dan Rekayasa Kebuadayaan. Yogyakarta: Kanisius.

Sugiama, A. G. (2011). Pengembangan Pariwisata Berbasis Konservasi Alam. Bandung: Guardaya Intimarta.

Suyitno. (2005). Pemanduan Wisata : (Tour Guiding). Yogyakarta: Graha Ilmu.

Wurzburger, et al (2009). Creative Tourism, a Global Conversation. Santa Fe: Sunstone Press. 
